Review

\title{
Loss of p16: A Bouncer of the Immunological Surveillance?
}

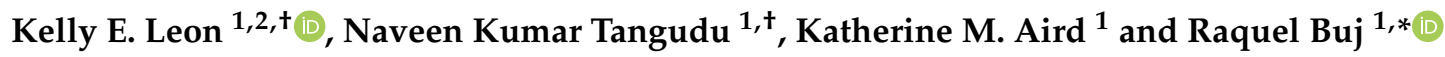 \\ 1 UPMC Hillman Cancer Center, Department of Pharmacology \& Chemical Biology, University of Pittsburgh \\ School of Medicine, Pittsburgh, PA 15213, USA; kel170@pitt.edu (K.E.L.); tangudunk@upmc.edu (N.K.T.); \\ katherine.aird@pitt.edu (K.M.A.) \\ 2 Biomedical Sciences Graduate Program, Penn State College of Medicine, Hershey, PA 15213, USA \\ * Correspondence: bujgomezr@upmc.edu; Tel.: +1-412-623-3241; Fax: +1-412-623-7709 \\ + These authors contributed equally to this work.
}

check for

updates

Citation: Leon, K.E.; Tangudu, N.K.; Aird, K.M.; Buj, R. Loss of p16: A Bouncer of the Immunological Surveillance? Life 2021, 11, 309. https://doi.org/10.3390/life11040309

Academic Editor: Markus Riessland

Received: 10 March 2021

Accepted: 30 March 2021

Published: 2 April 2021

Publisher's Note: MDPI stays neutral with regard to jurisdictional claims in published maps and institutional affiliations.

Copyright: (c) 2021 by the authors. Licensee MDPI, Basel, Switzerland. This article is an open access article distributed under the terms and conditions of the Creative Commons Attribution (CC BY) license (https:/ / creativecommons.org/licenses/by/ $4.0 /)$.

\begin{abstract}
INK} 4 \mathrm{~A}}$ (hereafter called p16) is an important tumor suppressor protein frequently suppressed in human cancer and highly upregulated in many types of senescence. Although its role as a cell cycle regulator is very well delineated, little is known about its other non-cell cycle-related roles. Importantly, recent correlative studies suggest that p16 may be a regulator of tissue immunological surveillance through the transcriptional regulation of different chemokines, interleukins and other factors secreted as part of the senescence-associated secretory phenotype (SASP). Here, we summarize the current evidence supporting the hypothesis that p16 is a regulator of tumor immunity.
\end{abstract}

Keywords: senescence-associated secretory phenotype (SASP); senescence; cell-cycle; melanoma; pancreatic adenocarcinoma; tumor infiltration; chemotherapy resistance

\section{Introduction}

Since the 19th century, immunologists have been speculating about the idea that the immune system may be a strong, efficient, and specific weapon against cancer (reviewed in [1]). However, it was not until the beginning of the 21st century that scientists began to understand the mechanisms behind tumor immunity and to develop immunotherapy regimens [2]. In parallel, the senescence field discovered that senescent cells, although in a stable state of cell cycle arrest [3], are highly active and acquire a pro-inflammatory microenvironment termed the senescence-associated secretory phenotype (SASP) $[4,5]$. Through the SASP, senescent cells can modify their microenvironment and regulate other cells, including cells of the immune system [5-10].

Among the multiple pathways that are commonly deregulated in cancer and senescence [11], the p16 ${ }^{\text {INK4A }}$ (hereafter called p16) pathway is particularly intriguing. On one hand, loss of p16 is a common feature of cancer that causes an increase in the proliferative capacity of the cell [12]; on the other hand, upregulation of p16 is a hallmark of senescence that contributes to the characteristic state of cell cycle arrest [13]. Interestingly, recent publications demonstrate that suppression of p16 correlates with decreased activity of immune cells [14-17], and our recent publication shows that p16 suppression decreases expression of the SASP [18]. Altogether these data suggest that p16 may have a, yet unknown, role in the regulation of tumor immunity that might have important implications in the treatment of cancers with low or null p16 expression. In this review, we describe the roles of p16 and the SASP in both senescence and cancer and dissect the latest publications that support the hypothesis that p16 may be a regulator of tumor immunity.

\section{2. p16 in Cancer and Senescence}

Cyclin Dependent Kinase Inhibitor 2A (CDKN2A) located in chromosome 9p21 is a tumor suppressor gene that encodes p14 ${ }^{\mathrm{ARF}}$ (p19ARF in mice, hereafter $\mathrm{p} 14$ and $\mathrm{p} 19$ ) and $\mathrm{p} 16$ proteins using two different open reading frames. While $\mathrm{p} 14^{\mathrm{ARF}}$ is involved in 
the regulation of the p53 pathway (reviewed in [19]), p16's canonical role is to inhibit the assembly and activation of the cyclin-dependent kinases CDK4/6, impairing the hyperphosphorylation of the retinoblastoma (RB) protein and the E2F-mediated expression of proliferation-promoting genes [20]. Due to its role as cell cycle brake, it is not surprising that $~ 50 \%$ of human cancer shows decreased expression of CDKN2A [12]. Interestingly, although the most common alterations of $\mathrm{p} 16$ are deletions and promoter hypermethylation affecting both p16 and p14 [21-23], cancer-associated mutations are more commonly found in p16 than p14 [24], suggesting a critical regulatory role of p16 in the cell. Importantly, loss of p16 alone is not enough to produce cancer, mainly because normal cells have other mechanisms to abrogate the cell cycle progression (e.g., p53, CHK1/2, APC) (reviewed in [25]). However, it has been shown that the suppression of p16 facilitates malignant transformation of cells upon different hyperproliferative signals and stressors such as oncogenes, oxidative stress, ionizing radiation, and others. All together these data suggest that tight regulation of p16 expression is critical to maintain healthy cellular proliferation.

On the other hand, p16 is known to be highly expressed during cellular senescence [26-28]. Senescence is a stable state of cell cycle arrest acquired upon different stressors such as aberrant proliferative signals or DNA damage among others [29]. Since cells are continuously affected by a wide variety of stressors, it is not surprising that a wide variety of senescence inducers exist, including: oncogenes, ionizing radiation, genotoxic chemicals, reactive oxygen species, chemotherapeutic agents or shortage in dNTPs among others (reviewed in [30]). Interestingly, in the vast majority of cases, the distinctive cell cycle arrest is achieved by upregulation of the p16 protein as a direct consequence of the pathways (e.g., p38 and ERK) [31-34], epigenetic factors (e.g., polycomb) [35-37] and transcription factors (e.g., ETS2 and AP-1) [38-41] altered by the senescence inducers. In this regard, several groups including our laboratory have shown that suppression of p16 can bypass senescence [42-46], indicating that p16 is critical to maintain the senescence phenotype.

In addition to its canonical role regulating the cell cycle, an increasing amount of evidence indicates that p16 has non-canonical, RB-independent roles. For instance, our laboratory found that suppression of $\mathrm{p} 16$ bypasses oncogene-induced senescence in part by promoting an increase in nucleotide and deoxyribonucleotide levels in a mechanism mediated by the mTORC1 complex and in an RB-independent manner (i.e., operating outside the cell cycle) [42]. Additionally, p16 has been found to regulate tumor suppressive miRNAs, mitochondria biogenesis, oxidative stress, transcription factors such as AP-1 and NF-KB or protein translation though EEF1A2 (reviewed in [47]). Altogether this shows that p16 is not a simple cell cycle brake, but also a regulator of other processes. Indeed, the observation that the large majority of cancer-associated mutations targeting $C D K N 2 A$ are mainly affecting the p16 open reading frame, reinforces the importance of p16 as a regulator of cellular physiology and stresses the necessity to further investigate p16-mediated regulatory processes.

\section{Role of SASP in Senescence and Cancer}

Together with the signature cell cycle arrest, the SASP is one of the most prominent phenotypes of senescent cells. The SASP is composed of various soluble and non-soluble factors including cytokines, chemokines, and proteases that are highly expressed and secreted by senescent cells, creating a pro-inflammatory microenvironment that affects themselves and other non-senescent cells in an autocrine and paracrine fashion, respectively $[48,49]$. In part because of its ability to modify the environment and impact the behavior of other cells, the SASP is tightly regulated at multiple levels. Transcriptionally, various factors (C/EBP $\beta$ and NF- $\kappa \beta$ ) [9,10], upstream regulators (p38, MAPK, GAT4A, p53, or ATM) [5,50-53] and non-coding RNAs (miRNAs, lncRNAs and circRNAs) [54] have been described to regulate SASP expression. Additionally, mTORC1-mediated translational regulation of MAPKAPK2 and IL1A has been shown to impact several SASP factors $[55,56]$. Finally, during senescence, there is a rearrangement of the genomic architecture leading 
to a new TAD (topologically associated domain) landscape [57,58]. This rearrangement is induced by changes in DNA methylation, nucleosome organization and histone modification, giving rise to the so-called senescence-associated heterochromatin foci (SAHF) [59-64]. There is a close relationship between the SAHF and the SASP and multiple epigenetic modifiers such as HMGB2, BRD4, MLL1, macroH2A1 or SIRT1, among others, have been shown to impact expression of the SASP [65-69]. In this regard, recent work from our laboratory shows that increased expression of the histone methyltransferase DOT1L upon oncogene-induced senescence, drives the expression of the major SASP-inducer IL1A though increased deposition of the active histone marks H3K79me2/3 at the IL1A gene loci [70].

Due to its inherent arrest of the cell-cycle described above, cellular senescence has been considered a bona fide tumor suppressor mechanism [71,72]. However, in the late 90s and early 2000s new experiments demonstrated that senescent cells can promote cellular proliferation and tumor growth due to acquisition of the SASP [7,73-75]. The SASP is highly dynamic and variable depending on several factors such as genetic background, cell type, the inducer of senescence, and the time of which senescence has occurred [76-79]. Due to its complex and variable nature, physiological roles of the SASP have not been well delineated. On one side, the SASP has been shown to contribute to the immunological surveillance, i.e., the process whereby the cells of the innate and adaptative immune system detect and destroy damaged cells [80-82]. For example, SASP secretion by senescence hepatocytes promotes T-cell mediated immunological surveillance within the liver, promoting the clearance of pre-malignant senescent cells and hence avoiding tumor progression [83]. On the other hand, the SASP has also been shown to contribute to numerous detrimental effects such as tumor promotion and progression and therapy resistance (reviewed in [84]). For instance, it has been described that some SASP secreted by senescent stromal cells promote an immunosuppressive microenvironment increasing the number of myeloid-derived suppressors cells (MDSCs), thus impairing immunological surveillance and promoting tumor growth $[85,86]$. In this regard, the dynamic nature of the SASP and its time-dependent regulation seems to be key to understanding the interaction with the immune system and hence the positive or negative outcome in the tumoral area [76,87]. Additionally, the SASP is not exclusive to senescent cells, and inflammatory phenotypes similar to the SASP, known as "SASP-like", have been described in tumor cells [67,88]. Indeed our laboratory has found that similar to senescent cells, different tumor types display different SASP (SASP-like) profiles [18], further demonstrating the wide variability of the SASP. Whether this indicates that those tumors bypassed senescence at some point during their malignant transformation is still unknown and more research is needed. However, it is becoming clearer that both the senescent cells in the tumor environment and the tumor cells themselves contribute to the maintenance of a SASP-driven inflammatory microenvironment. Therefore, it is imperative to delineate the mechanisms of SASP expression and secretion as well as map the SASP composition upon different conditions, tissue types and timeframes to design efficient and personalized immunotherapies.

\section{4. p16 Regulation of Tumor Immunity}

We previously described that canonical and non-canonical roles of p16 in part regulate cellular homeostasis. However, is it possible that $\mathrm{p} 16$ regulates other processes that impact the cellular microenvironment? Recent evidence demonstrates that loss of CDKN2A expression in tumor cells correlates with different immunological processes within the tumor that may impair immunological surveillance suggesting that p16 not only regulates cellular homeostasis but also tissue homeostasis. Below we will dissect the current evidence that implicates p16 as a regulator of intratumor immunity.

The first piece of evidence was published by Balli et al., [14]. These authors used a previously published expression signature based on two key cytolytic effectors (GZMA and PRF1) upregulated upon CD8+ T cell activation [89] to assess the intratumoral cytolytic Tcell activity in pancreatic adenocarcinoma samples from The Cancer Genome Atlas (TCGA). 
Interestingly, non-silent mutations and deletions of $C D K N 2 A$ correlated with decreased cytolytic activity. One year later, Wartenberg et al. [15] investigated the immune cell composition within the microenvironment in a series of pancreatic ductal adenocarcinoma and cross compared it with a high-throughput analysis of somatic mutations. They found that high mutation rates of $C D K N 2 A$ correlate with a so-called immune-escape microenvironment, which is a microenvironment poor in T and B cells and enriched in FOXP3+ Tregs. Consistent with this result, Morrison et al. [16] found that loss of CDKN2A significantly correlates with immune deserts, defined by a profile of 394 immune transcripts. These pieces of evidence suggest that low $C D K N 2 A$ expression both impacts the number and the activity of the intratumoral immune cells. Moreover, suppression of CDKN2A in mesenchymal stromal cells has been shown to decrease CD11b+Gr-1 ${ }^{\text {hi }}$ neutrophils, CD11b+Gr1 $1^{\text {low }}$ monocytes and CD45-CD31-Integrin $\alpha 7+$ satellite cells in a model of chronic inflammatory myopathy [17]. Although all those investigations are based on correlative analysis, these data may indicate that $C D K N 2 A$ is necessary for regulation of the physiological immune response upon different inflammatory events. However, it should be noted that there are some publications that disagree with this thesis [90-92]. Thus, further mechanistic studies are necessary to determine in which circumstances suppression of CDKN2A in non-immune cells decreases immunological surveillance.

How does the suppression of p16 abrogate immunological surveillance? A recent publication from our laboratory demonstrates that the specific knockdown of p16 in oncogeneinduced senescent cells leads to decreased expression of several SASP genes, including the most well characterized cytokines IL6, CXCL8 and CSF3, the proteases MMP3, PLAU and PLAT, the growth factors AREG, EREG and VEGFA and the glycoprotein ICAM1 [18]. Early suppression of p16 bypasses senescence in vitro and in vivo [18,42,43,93,94]; however, we demonstrated that knockdown of p16 at late time points upon oncogene-induced senescence does not bypass senescence but still decreases the expression of IL6 and CXCL8 [18], suggesting that this is uncoupled from the senescence-associated cell cycle arrest. Additionally, we found that low CDKN2A expression in tumors of 6 different types, including melanoma and pancreatic adenocarcinoma, correlated with a decreased SASP signature [18], further demonstrating the role of p16 in regulation of the SASP. Consistent with our observation, other articles have found decreased expression of SASP factors upon suppression of p16 in a murine model of intervertebral disc regeneration [95] and liver fibrosis [96]. Interestingly, induction of senescence through p16 overexpression does not increase SASP gene expression [50], suggesting that p16 is necessary but not sufficient to induce the SASP. As we have previously discussed, the SASP has pleiotropic and context-dependent effects that can both promote tumor progression and enhance anti-tumor immunity (Reviewed in [97]); thus, it is plausible that the observed decreased of immunological surveillance in tumors with suppression of $C D K N 2 A$ is mediated by decreased SASP. More studies are needed to understand the exact mechanism whereby suppression of p16 leads to decreased SASP gene expression and whether this leads to decreased immunological surveillance and tumor growth. Additionally, in those tumors where loss of p16 occurs due to deletion of the chromosome 9p21 locus, adjacent genes such as MTAP and the interferon $\alpha$ and $\beta$ cluster may be also affected and lost $[98,99]$. Previous studies have suggested that melanomas with low MTAP expression have decreased cGAS-STING signaling [100], a pathway strongly involved in SASP expression though NF- $\mathrm{k} \beta$ regulation [101-103]. Additionally, codeletion of $C D K N 2 A$ and the interferon $\alpha$ and $\beta$ cluster has been linked with decreased expression of immune cell genes in melanoma tumors [104]. Therefore, it is likely that multiple mechanisms exist in tumors with loss of 9p21 to suppress SASP gene expression and to modulate the tumor microenvironment.

How is immunological surveillance initiated on the tumor microenvironment? A large amount of evidence suggests that intratumoral senescence induction is critical for activation of the immune system and clearance of cancer cells $[83,86,105,106]$, and abrogation of senescence-inducing pathways, mainly p16 and p21, have been shown to be critical to promote immune-checkpoint inhibitors resistance $[107,108]$. Thus, which is the main 
requirement for intratumoral immune system activation: senescence induction or high p16 expression? This is a complicated question since most senescent cells upregulate p16 as a manner to maintain the cell cycle arrest [26,109], and early abrogation of p16 activity overcomes senescence in vitro and in vivo $[42,43,93,94]$, thus likely reducing the intratumoral senescence burden. In this regard, our previous data demonstrate that although etoposide can induce senescence in melanoma cells with stable p16 knockdown, these cells fail to increase the expression of IL6 and CXCL8 [18]. Moreover, although tumors with low p16 expression show a significant decrease in SASP factors, we did not observe differences in the amount of intratumoral senescent cells [18]. Interestingly, Novais et al. also found that suppression of p16 in a model of intervertebral disc regeneration decreases the SASP without altering the onset of senescence [110]. Altogether, these data suggest that p16 may regulate the tumor microenvironment and by extension intratumor immunity independently of senescence induction. This indeed, may explain previous observations where overexpression of p16 induces a cell cycle arrest without the SASP [50].

Importantly, the lack of SASP expression observed in cells with p16 suppression indicates that induction of senescence as a mechanism to abrogate malignant proliferation may be a suitable and safe therapy for cancers with null or very low p16 expression. More experiments analyzing the immune response landscape as well as the mechanisms by which p16 decreases SASP are needed to understand this observation and to develop better treatments for the $\sim 50 \%$ of human cancers with decreased p16 expression [12].

\section{Conclusions}

In conclusion, suppression of p16 in tumor cells decreases the expression of interleukins, chemokines and other factors belonging to the SASP that in turn may remodel the tumor microenvironment, thereby impairing immunological surveillance (Figure 1). The observation that suppression of p16 decreases SASP gene expression is sustained by different studies in multiple models including cancer and fibrosis. Additionally, there are multiple high-throughput correlative studies in different diseases suggesting that low $C D K N 2 A$ activity correlates with a decreased number and activity of intratumoral immune cells. Altogether, this suggests that $\mathrm{p} 16$ suppression is not only a cell cycle regulator but also a regulator of tissue homeostasis. More research is needed to understand whether this is a direct or indirect effect and whether this is due to canonical or non-canonical p16 roles. This is imperative since currently there are not pharmacological treatments specifically for p16-non canonical pathways [47].

A

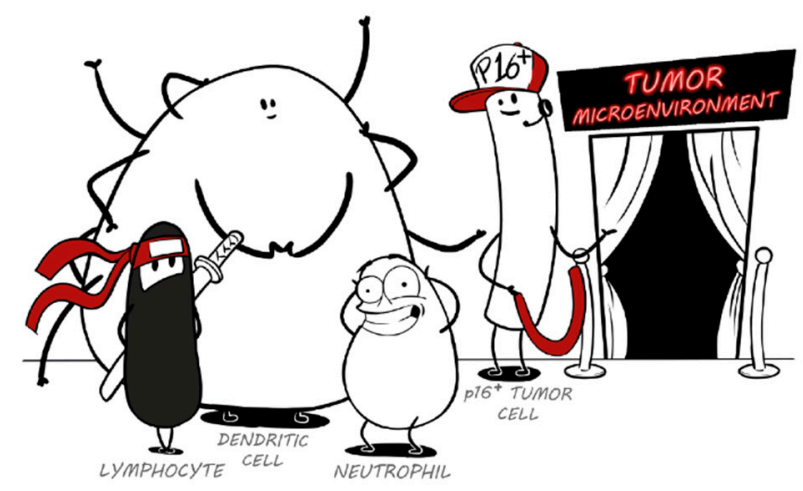

B

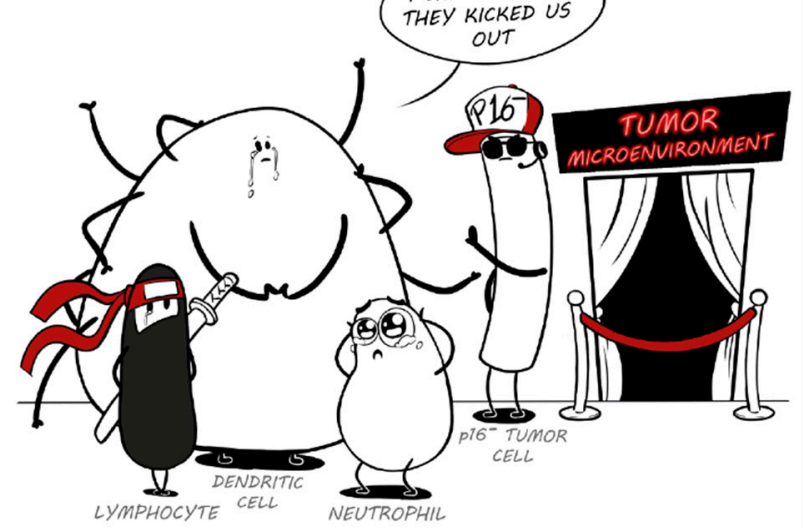

Figure 1. Cartoon representing the hypothesis discussed in this review: the possible role of p16 in regulation of immunological surveillance. (A) Represents a p16 positive tumor where cells of the immune system are invited into the tumor microenvironment and hence tumor immunosurveillance is fostered. (B) Represents a p16-null tumor, which correlates with decreased number and activity of immune cells, thus impairing immunosurveillance and promoting tumor growth. 
Funding: This work was supported by grants from the National Institutes of Health (F31CA250366 to K.E.L. and R37CA240625 to K.M.A.).

Institutional Review Board Statement: Not applicable.

Informed Consent Statement: Not applicable.

Data Availability Statement: Not applicable.

Acknowledgments: We thank Francisco J. Vazquez-Moreno for his beautiful cartoon in Figure 1.

Conflicts of Interest: The authors declare no conflict of interest.

\section{References}

1. Decker, W.K.; da Silva, R.F.; Sanabria, M.H.; Angelo, L.S.; Guimaraes, F.; Burt, B.M.; Kheradmand, F.; Paust, S. Cancer Immunotherapy: Historical Perspective of a Clinical Revolution and Emerging Preclinical Animal Models. Front. Immunol. 2017, 8 , 829. [CrossRef]

2. Vaddepally, R.K.; Kharel, P.; Pandey, R.; Garje, R.; Chandra, A.B. Review of Indications of FDA-Approved Immune Checkpoint Inhibitors per NCCN Guidelines with the Level of Evidence. Cancers 2020, 12, 738. [CrossRef]

3. Aird, K.M.; Zhang, R. Nucleotide metabolism, oncogene-induced senescence and cancer. Cancer Lett. 2015, 356, 204-210. [CrossRef]

4. Kuilman, T.; Peeper, D.S. Senescence-messaging secretome: SMS-ing cellular stress. Nat. Rev. Cancer 2009, 9, 81-94. [CrossRef]

5. Coppe, J.P.; Patil, C.K.; Rodier, F.; Sun, Y.; Munoz, D.P.; Goldstein, J.; Nelson, P.S.; Desprez, P.Y.; Campisi, J. Senescence-associated secretory phenotypes reveal cell-nonautonomous functions of oncogenic RAS and the p53 tumor suppressor. PLoS Biol. 2008, 6, 2853-2868. [CrossRef]

6. Zhang, H.; Pan, K.H.; Cohen, S.N. Senescence-specific gene expression fingerprints reveal cell-type-dependent physical clustering of up-regulated chromosomal loci. Proc. Natl. Acad. Sci. USA 2003, 100, 3251-3256. [CrossRef]

7. Bavik, C.; Coleman, I.; Dean, J.P.; Knudsen, B.; Plymate, S.; Nelson, P.S. The gene expression program of prostate fibroblast senescence modulates neoplastic epithelial cell proliferation through paracrine mechanisms. Cancer Res. 2006, 66, 794-802. [CrossRef] [PubMed]

8. Wajapeyee, N.; Serra, R.W.; Zhu, X.; Mahalingam, M.; Green, M.R. Oncogenic BRAF induces senescence and apoptosis through pathways mediated by the secreted protein IGFBP7. Cell 2008, 132, 363-374. [CrossRef] [PubMed]

9. Kuilman, T.; Michaloglou, C.; Vredeveld, L.C.; Douma, S.; van Doorn, R.; Desmet, C.J.; Aarden, L.A.; Mooi, W.J.; Peeper, D.S. Oncogene-induced senescence relayed by an interleukin-dependent inflammatory network. Cell 2008, 133, 1019-1031. [CrossRef]

10. Acosta, J.C.; O’Loghlen, A.; Banito, A.; Guijarro, M.V.; Augert, A.; Raguz, S.; Fumagalli, M.; Da Costa, M.; Brown, C.; Popov, N.; et al. Chemokine signaling via the CXCR2 receptor reinforces senescence. Cell 2008, 133, 1006-1018. [CrossRef] [PubMed]

11. Campisi, J. Aging, cellular senescence, and cancer. Annu. Rev. Physiol. 2013, 75, 685-705. [CrossRef] [PubMed]

12. Gonzalez, S.; Serrano, M. A new mechanism of inactivation of the INK4/ARF locus. Cell Cycle 2006, 5, 1382-1384. [CrossRef] [PubMed]

13. Sharpless, N.E.; Sherr, C.J. Forging a signature of in vivo senescence. Nat. Rev. Cancer 2015, 15, 397-408. [CrossRef] [PubMed]

14. Balli, D.; Rech, A.J.; Stanger, B.Z.; Vonderheide, R.H. Immune Cytolytic Activity Stratifies Molecular Subsets of Human Pancreatic Cancer. Clin. Cancer Res. 2017, 23, 3129-3138. [CrossRef] [PubMed]

15. Wartenberg, M.; Cibin, S.; Zlobec, I.; Vassella, E.; Eppenberger-Castori, S.; Terracciano, L.; Eichmann, M.D.; Worni, M.; Gloor, B.; Perren, A.; et al. Integrated Genomic and Immunophenotypic Classification of Pancreatic Cancer Reveals Three Distinct Subtypes with Prognostic/Predictive Significance. Clin. Cancer Res. 2018, 24, 4444-4454. [CrossRef] [PubMed]

16. Morrison, C.; Pabla, S.; Conroy, J.M.; Nesline, M.K.; Glenn, S.T.; Dressman, D.; Papanicolau-Sengos, A.; Burgher, B.; Andreas, J.; Giamo, V.; et al. Predicting response to checkpoint inhibitors in melanoma beyond PD-L1 and mutational burden. J. Immunother. Cancer 2018, 6, 32. [CrossRef]

17. Chikenji, T.S.; Saito, Y.; Konari, N.; Nakano, M.; Mizue, Y.; Otani, M.; Fujimiya, M. p16(INK4A)-expressing mesenchymal stromal cells restore the senescence-clearance-regeneration sequence that is impaired in chronic muscle inflammation. EBioMedicine 2019, 44, 86-97. [CrossRef]

18. Buj, R.; Leon, K.E.; Anguelov, M.A.; Aird, K.M. Suppression of p16 alleviates the senescence-associated secretory phenotype. Aging 2021, 13, 3290. [CrossRef]

19. Ozenne, P.; Eymin, B.; Brambilla, E.; Gazzeri, S. The ARF tumor suppressor: Structure, functions and status in cancer. Int. J. Cancer 2010, 127, 2239-2247. [CrossRef]

20. Sherr, C.J. The INK4a/ARF network in tumour suppression. Nat. Rev. Mol. Cell Biol. 2001, 2, 731-737. [CrossRef]

21. Esteller, M.; Corn, P.G.; Baylin, S.B.; Herman, J.G. A gene hypermethylation profile of human cancer. Cancer Res. 2001, 61, 3225-3229. [PubMed]

22. Ruas, M.; Brookes, S.; McDonald, N.Q.; Peters, G. Functional evaluation of tumour-specific variants of p16INK4a/CDKN2A: Correlation with protein structure information. Oncogene 1999, 18, 5423-5434. [CrossRef] 
23. Inoue, K.; Fry, E.A. Aberrant expression of p16(INK4a) in human cancers-A new biomarker? Cancer Rep. Rev. 2018, 2. [CrossRef] [PubMed]

24. Quelle, D.E.; Cheng, M.; Ashmun, R.A.; Sherr, C.J. Cancer-associated mutations at the INK4a locus cancel cell cycle arrest by p16INK4a but not by the alternative reading frame protein p19ARF. Proc. Natl. Acad. Sci. USA 1997, 94, 669-673. [CrossRef]

25. Barnum, K.J.; O'Connell, M.J. Cell cycle regulation by checkpoints. Methods Mol. Biol. 2014, 1170, 29-40. [CrossRef]

26. Serrano, M.; Lin, A.W.; McCurrach, M.E.; Beach, D.; Lowe, S.W. Oncogenic ras provokes premature cell senescence associated with accumulation of p53 and p16INK4a. Cell 1997, 88, 593-602. [CrossRef]

27. Liu, J.Y.; Souroullas, G.P.; Diekman, B.O.; Krishnamurthy, J.; Hall, B.M.; Sorrentino, J.A.; Parker, J.S.; Sessions, G.A.; Gudkov, A.V.; Sharpless, N.E. Cells exhibiting strong p16 (INK4a) promoter activation in vivo display features of senescence. Proc. Natl. Acad. Sci. USA 2019, 116, 2603-2611. [CrossRef]

28. Baker, D.J.; Childs, B.G.; Durik, M.; Wijers, M.E.; Sieben, C.J.; Zhong, J.; Saltness, R.A.; Jeganathan, K.B.; Verzosa, G.C.; Pezeshki, A.; et al. Naturally occurring p16(Ink4a)-positive cells shorten healthy lifespan. Nature 2016, 530, 184-189. [CrossRef]

29. Gil, J.; Peters, G. Regulation of the INK4b-ARF-INK4a tumour suppressor locus: All for one or one for all. Nat. Rev. Mol. Cell Biol. 2006, 7, 667-677. [CrossRef]

30. Itahana, K.; Campisi, J.; Dimri, G.P. Mechanisms of cellular senescence in human and mouse cells. Biogerontology 2004, 5, 1-10. [CrossRef]

31. Bulavin, D.V.; Phillips, C.; Nannenga, B.; Timofeev, O.; Donehower, L.A.; Anderson, C.W.; Appella, E.; Fornace, A.J., Jr. Inactivation of the Wip1 phosphatase inhibits mammary tumorigenesis through p38 MAPK-mediated activation of the p16(Ink4a)-p19(Arf) pathway. Nat. Genet. 2004, 36, 343-350. [CrossRef]

32. Deng, Q.; Liao, R.; Wu, B.L.; Sun, P. High intensity ras signaling induces premature senescence by activating p38 pathway in primary human fibroblasts. J. Biol. Chem. 2004, 279, 1050-1059. [CrossRef]

33. Lin, A.W.; Barradas, M.; Stone, J.C.; van Aelst, L.; Serrano, M.; Lowe, S.W. Premature senescence involving p53 and p16 is activated in response to constitutive MEK/MAPK mitogenic signaling. Genes Dev. 1998, 12, 3008-3019. [CrossRef] [PubMed]

34. Wang, W.; Chen, J.X.; Liao, R.; Deng, Q.; Zhou, J.J.; Huang, S.; Sun, P. Sequential activation of the MEK-extracellular signalregulated kinase and $\mathrm{MKK} 3 / 6$-p38 mitogen-activated protein kinase pathways mediates oncogenic ras-induced premature senescence. Mol. Cell. Biol. 2002, 22, 3389-3403. [CrossRef] [PubMed]

35. Bracken, A.P.; Kleine-Kohlbrecher, D.; Dietrich, N.; Pasini, D.; Gargiulo, G.; Beekman, C.; Theilgaard-Monch, K.; Minucci, S.; Porse, B.T.; Marine, J.C.; et al. The Polycomb group proteins bind throughout the INK4A-ARF locus and are disassociated in senescent cells. Genes Dev. 2007, 21, 525-530. [CrossRef] [PubMed]

36. Dietrich, N.; Bracken, A.P.; Trinh, E.; Schjerling, C.K.; Koseki, H.; Rappsilber, J.; Helin, K.; Hansen, K.H. Bypass of senescence by the polycomb group protein CBX8 through direct binding to the INK4A-ARF locus. EMBO J. 2007, 26, 1637-1648. [CrossRef] [PubMed]

37. Ito, T.; Teo, Y.V.; Evans, S.A.; Neretti, N.; Sedivy, J.M. Regulation of Cellular Senescence by Polycomb Chromatin Modifiers through Distinct DNA Damage- and Histone Methylation-Dependent Pathways. Cell Rep. 2018, 22, 3480-3492. [CrossRef] [PubMed]

38. Nakade, K.; Pan, J.; Yamasaki, T.; Murata, T.; Wasylyk, B.; Yokoyama, K.K. JDP2 (Jun Dimerization Protein 2)-deficient mouse embryonic fibroblasts are resistant to replicative senescence. J. Biol. Chem. 2009, 284, 10808-10817. [CrossRef]

39. Ohtani, N.; Zebedee, Z.; Huot, T.J.; Stinson, J.A.; Sugimoto, M.; Ohashi, Y.; Sharrocks, A.D.; Peters, G.; Hara, E. Opposing effects of Ets and Id proteins on p16INK4a expression during cellular senescence. Nature 2001, 409, 1067-1070. [CrossRef] [PubMed]

40. Passegue, E.; Wagner, E.F. JunB suppresses cell proliferation by transcriptional activation of p16(INK4a) expression. EMBO J. 2000, 19, 2969-2979. [CrossRef]

41. Swarbrick, A.; Roy, E.; Allen, T.; Bishop, J.M. Id1 cooperates with oncogenic Ras to induce metastatic mammary carcinoma by subversion of the cellular senescence response. Proc. Natl. Acad. Sci. USA 2008, 105, 5402-5407. [CrossRef]

42. Buj, R.; Chen, C.W.; Dahl, E.S.; Leon, K.E.; Kuskovsky, R.; Maglakelidze, N.; Navaratnarajah, M.; Zhang, G.; Doan, M.T.; Jiang, H.; et al. Suppression of p16 Induces mTORC1-Mediated Nucleotide Metabolic Reprogramming. Cell Rep. 2019, 28, 1971-1980.e1978. [CrossRef]

43. Damsky, W.; Micevic, G.; Meeth, K.; Muthusamy, V.; Curley, D.P.; Santhanakrishnan, M.; Erdelyi, I.; Platt, J.T.; Huang, L.; Theodosakis, N.; et al. mTORC1 activation blocks BrafV600E-induced growth arrest but is insufficient for melanoma formation. Cancer Cell 2015, 27, 41-56. [CrossRef]

44. Dankort, D.; Filenova, E.; Collado, M.; Serrano, M.; Jones, K.; McMahon, M. A new mouse model to explore the initiation, progression, and therapy of BRAFV600E-induced lung tumors. Genes Dev. 2007, 21, 379-384. [CrossRef]

45. Goel, V.K.; Ibrahim, N.; Jiang, G.; Singhal, M.; Fee, S.; Flotte, T.; Westmoreland, S.; Haluska, F.S.; Hinds, P.W.; Haluska, F.G. Melanocytic nevus-like hyperplasia and melanoma in transgenic BRAFV600E mice. Oncogene 2009, 28, 2289-2298. [CrossRef]

46. Haferkamp, S.; Becker, T.M.; Scurr, L.L.; Kefford, R.F.; Rizos, H. p16INK4a-induced senescence is disabled by melanoma-associated mutations. Aging Cell 2008, 7, 733-745. [CrossRef]

47. Buj, R.; Aird, K.M. p16: Cycling off the beaten path. Mol. Cell. Oncol. 2019, 6, e1677140. [CrossRef]

48. Coppe, J.P.; Desprez, P.Y.; Krtolica, A.; Campisi, J. The senescence-associated secretory phenotype: The dark side of tumor suppression. Annu. Rev. Pathol. 2010, 5, 99-118. [CrossRef] [PubMed] 
49. Gonzalez-Meljem, J.M.; Apps, J.R.; Fraser, H.C.; Martinez-Barbera, J.P. Paracrine roles of cellular senescence in promoting tumourigenesis. Br. J. Cancer 2018, 118, 1283-1288. [CrossRef] [PubMed]

50. Coppe, J.P.; Rodier, F.; Patil, C.K.; Freund, A.; Desprez, P.Y.; Campisi, J. Tumor suppressor and aging biomarker p16(INK4a) induces cellular senescence without the associated inflammatory secretory phenotype. J. Biol. Chem. 2011, $286,36396-36403$. [CrossRef] [PubMed]

51. Kang, C.; Xu, Q.; Martin, T.D.; Li, M.Z.; Demaria, M.; Aron, L.; Lu, T.; Yankner, B.A.; Campisi, J.; Elledge, S.J. The DNA damage response induces inflammation and senescence by inhibiting autophagy of GATA4. Science 2015, 349, aaa5612. [CrossRef]

52. Malaquin, N.; Olivier, M.A.; Martinez, A.; Nadeau, S.; Sawchyn, C.; Coppe, J.P.; Cardin, G.; Mallette, F.A.; Campisi, J.; Rodier, F. Non-canonical ATM/MRN activities temporally define the senescence secretory program. EMBO Rep. 2020, 21 , e50718. [CrossRef] [PubMed]

53. Rodier, F.; Coppe, J.P.; Patil, C.K.; Hoeijmakers, W.A.; Munoz, D.P.; Raza, S.R.; Freund, A.; Campeau, E.; Davalos, A.R.; Campisi, J. Persistent DNA damage signalling triggers senescence-associated inflammatory cytokine secretion. Nat. Cell. Biol. 2009, 11, 973-979. [CrossRef] [PubMed]

54. Panda, A.C.; Abdelmohsen, K.; Gorospe, M. SASP regulation by noncoding RNA. Mech. Ageing Dev. 2017, 168, 37-43. [CrossRef] [PubMed]

55. Herranz, N.; Gallage, S.; Mellone, M.; Wuestefeld, T.; Klotz, S.; Hanley, C.J.; Raguz, S.; Acosta, J.C.; Innes, A.J.; Banito, A.; et al. mTOR regulates MAPKAPK2 translation to control the senescence-associated secretory phenotype. Nat. Cell. Biol. 2015, 17, 1205-1217. [CrossRef] [PubMed]

56. Laberge, R.M.; Sun, Y.; Orjalo, A.V.; Patil, C.K.; Freund, A.; Zhou, L.; Curran, S.C.; Davalos, A.R.; Wilson-Edell, K.A.; Liu, S.; et al. MTOR regulates the pro-tumorigenic senescence-associated secretory phenotype by promoting IL1A translation. Nat. Cell. Biol. 2015, 17, 1049-1061. [CrossRef]

57. Chandra, T.; Ewels, P.A.; Schoenfelder, S.; Furlan-Magaril, M.; Wingett, S.W.; Kirschner, K.; Thuret, J.Y.; Andrews, S.; Fraser, P.; Reik, W. Global reorganization of the nuclear landscape in senescent cells. Cell Rep. 2015, 10, 471-483. [CrossRef]

58. Criscione, S.W.; De Cecco, M.; Siranosian, B.; Zhang, Y.; Kreiling, J.A.; Sedivy, J.M.; Neretti, N. Reorganization of chromosome architecture in replicative cellular senescence. Sci. Adv. 2016, 2, e1500882. [CrossRef]

59. Narita, M.; Nunez, S.; Heard, E.; Narita, M.; Lin, A.W.; Hearn, S.A.; Spector, D.L.; Hannon, G.J.; Lowe, S.W. Rb-mediated heterochromatin formation and silencing of E2F target genes during cellular senescence. Cell 2003, 113, 703-716. [CrossRef]

60. Zhang, R.; Poustovoitov, M.V.; Ye, X.; Santos, H.A.; Chen, W.; Daganzo, S.M.; Erzberger, J.P.; Serebriiskii, I.G.; Canutescu, A.A.; Dunbrack, R.L.; et al. Formation of MacroH2A-containing senescence-associated heterochromatin foci and senescence driven by ASF1a and HIRA. Dev. Cell 2005, 8, 19-30. [CrossRef]

61. Sakaki, M.; Ebihara, Y.; Okamura, K.; Nakabayashi, K.; Igarashi, A.; Matsumoto, K.; Hata, K.; Kobayashi, Y.; Maehara, K. Potential roles of DNA methylation in the initiation and establishment of replicative senescence revealed by array-based methylome and transcriptome analyses. PLoS ONE 2017, 12, e0171431. [CrossRef]

62. Zhang, R.; Chen, W.; Adams, P.D. Molecular dissection of formation of senescence-associated heterochromatin foci. Mol. Cell. Biol. 2007, 27, 2343-2358. [CrossRef]

63. Cruickshanks, H.A.; McBryan, T.; Nelson, D.M.; Vanderkraats, N.D.; Shah, P.P.; van Tuyn, J.; Singh Rai, T.; Brock, C.; Donahue, G.; Dunican, D.S.; et al. Senescent cells harbour features of the cancer epigenome. Nat. Cell. Biol. 2013, 15, 1495-1506. [CrossRef]

64. Parry, A.J.; Hoare, M.; Bihary, D.; Hansel-Hertsch, R.; Smith, S.; Tomimatsu, K.; Mannion, E.; Smith, A.; D’Santos, P.; Russell, I.A.; et al. NOTCH-mediated non-cell autonomous regulation of chromatin structure during senescence. Nat. Commun. 2018, 9, 1840. [CrossRef]

65. Aird, K.M.; Iwasaki, O.; Kossenkov, A.V.; Tanizawa, H.; Fatkhutdinov, N.; Bitler, B.G.; Le, L.; Alicea, G.; Yang, T.L.; Johnson, F.B.; et al. HMGB2 orchestrates the chromatin landscape of senescence-associated secretory phenotype gene loci. J. Cell Biol. 2016, 215, 325-334. [CrossRef] [PubMed]

66. Tasdemir, N.; Banito, A.; Roe, J.S.; Alonso-Curbelo, D.; Camiolo, M.; Tschaharganeh, D.F.; Huang, C.H.; Aksoy, O.; Bolden, J.E.; Chen, C.C.; et al. BRD4 Connects Enhancer Remodeling to Senescence Immune Surveillance. Cancer Discov. 2016, 6, 612-629. [CrossRef] [PubMed]

67. Capell, B.C.; Drake, A.M.; Zhu, J.; Shah, P.P.; Dou, Z.; Dorsey, J.; Simola, D.F.; Donahue, G.; Sammons, M.; Rai, T.S.; et al. MLL1 is essential for the senescence-associated secretory phenotype. Genes Dev. 2016, 30, 321-336. [CrossRef] [PubMed]

68. Chen, H.; Ruiz, P.D.; McKimpson, W.M.; Novikov, L.; Kitsis, R.N.; Gamble, M.J. MacroH2A1 and ATM Play Opposing Roles in Paracrine Senescence and the Senescence-Associated Secretory Phenotype. Mol. Cell 2015, 59, 719-731. [CrossRef] [PubMed]

69. Hayakawa, T.; Iwai, M.; Aoki, S.; Takimoto, K.; Maruyama, M.; Maruyama, W.; Motoyama, N. SIRT1 suppresses the senescenceassociated secretory phenotype through epigenetic gene regulation. PLoS ONE 2015, 10, e0116480. [CrossRef]

70. Leon, K.E.; Buj, R.; Lesko, E.; Dahl, E.S.; Chen, C.-W.; Imamura, Y.; Kossenkov, A.V.; Hobbs, R.P.; Arid, K.M. DOT1L modulates the senescence-associated secretory phenotype through epigenetic regulation of IL1A. bioRxiv Prepr. Serv. Biol. 2020. [CrossRef]

71. Campisi, J. Cellular senescence as a tumor-suppressor mechanism. Trends Cell Biol. 2001, 11, S27-S31. [CrossRef]

72. Dimri, G.P. What has senescence got to do with cancer? Cancer Cell 2005, 7, 505-512. [CrossRef]

73. Krtolica, A.; Parrinello, S.; Lockett, S.; Desprez, P.Y.; Campisi, J. Senescent fibroblasts promote epithelial cell growth and tumorigenesis: A link between cancer and aging. Proc. Natl. Acad. Sci. USA 2001, 98, 12072-12077. [CrossRef] [PubMed] 
74. Bhatia, B.; Multani, A.S.; Patrawala, L.; Chen, X.; Calhoun-Davis, T.; Zhou, J.; Schroeder, L.; Schneider-Broussard, R.; Shen, J.; Pathak, S.; et al. Evidence that senescent human prostate epithelial cells enhance tumorigenicity: Cell fusion as a potential mechanism and inhibition by p16INK4a and hTERT. Int. J. Cancer 2008, 122, 1483-1495. [CrossRef]

75. Coppe, J.P.; Kauser, K.; Campisi, J.; Beausejour, C.M. Secretion of vascular endothelial growth factor by primary human fibroblasts at senescence. J. Biol. Chem. 2006, 281, 29568-29574. [CrossRef] [PubMed]

76. Hoare, M.; Ito, Y.; Kang, T.W.; Weekes, M.P.; Matheson, N.J.; Patten, D.A.; Shetty, S.; Parry, A.J.; Menon, S.; Salama, R.; et al. NOTCH1 mediates a switch between two distinct secretomes during senescence. Nat. Cell Biol. 2016, 18, 979-992. [CrossRef] [PubMed]

77. Basisty, N.; Kale, A.; Jeon, O.H.; Kuehnemann, C.; Payne, T.; Rao, C.; Holtz, A.; Shah, S.; Sharma, V.; Ferrucci, L.; et al. A proteomic atlas of senescence-associated secretomes for aging biomarker development. PLoS Biol. 2020, 18, e3000599. [CrossRef]

78. Rao, S.G.; Jackson, J.G. SASP: Tumor Suppressor or Promoter? Yes! Trends Cancer 2016, 2, 676-687. [CrossRef] [PubMed]

79. Hernandez-Segura, A.; de Jong, T.V.; Melov, S.; Guryev, V.; Campisi, J.; Demaria, M. Unmasking Transcriptional Heterogeneity in Senescent Cells. Curr. Biol. 2017, 27, 2652-2660.e2654. [CrossRef]

80. Krizhanovsky, V.; Yon, M.; Dickins, R.A.; Hearn, S.; Simon, J.; Miething, C.; Yee, H.; Zender, L.; Lowe, S.W. Senescence of activated stellate cells limits liver fibrosis. Cell 2008, 134, 657-667. [CrossRef]

81. Jun, J.I.; Lau, L.F. The matricellular protein CCN1 induces fibroblast senescence and restricts fibrosis in cutaneous wound healing. Nat. Cell Biol. 2010, 12, 676-685. [CrossRef]

82. Pitiyage, G.N.; Slijepcevic, P.; Gabrani, A.; Chianea, Y.G.; Lim, K.P.; Prime, S.S.; Tilakaratne, W.M.; Fortune, F.; Parkinson, E.K. Senescent mesenchymal cells accumulate in human fibrosis by a telomere-independent mechanism and ameliorate fibrosis through matrix metalloproteinases. J. Pathol. 2011, 223, 604-617. [CrossRef] [PubMed]

83. Kang, T.W.; Yevsa, T.; Woller, N.; Hoenicke, L.; Wuestefeld, T.; Dauch, D.; Hohmeyer, A.; Gereke, M.; Rudalska, R.; Potapova, A.; et al. Senescence surveillance of pre-malignant hepatocytes limits liver cancer development. Nature 2011, 479, 547-551. [CrossRef]

84. Georgilis, A.; Gil, J. Controlling secretion to limit chemoresistance. Genes Dev. 2016, 30, 1791-1792. [CrossRef] [PubMed]

85. Ruhland, M.K.; Loza, A.J.; Capietto, A.H.; Luo, X.; Knolhoff, B.L.; Flanagan, K.C.; Belt, B.A.; Alspach, E.; Leahy, K.; Luo, J.; et al. Stromal senescence establishes an immunosuppressive microenvironment that drives tumorigenesis. Nat. Commun. 2016, 7, 11762. [CrossRef] [PubMed]

86. Toso, A.; Revandkar, A.; Di Mitri, D.; Guccini, I.; Proietti, M.; Sarti, M.; Pinton, S.; Zhang, J.; Kalathur, M.; Civenni, G.; et al. Enhancing chemotherapy efficacy in Pten-deficient prostate tumors by activating the senescence-associated antitumor immunity. Cell Rep. 2014, 9, 75-89. [CrossRef]

87. Teo, Y.V.; Rattanavirotkul, N.; Olova, N.; Salzano, A.; Quintanilla, A.; Tarrats, N.; Kiourtis, C.; Muller, M.; Green, A.R.; Adams, P.D.; et al. Notch Signaling Mediates Secondary Senescence. Cell Rep. 2019, 27, 997-1007.e1005. [CrossRef] [PubMed]

88. Zelenay, S.; van der Veen, A.G.; Bottcher, J.P.; Snelgrove, K.J.; Rogers, N.; Acton, S.E.; Chakravarty, P.; Girotti, M.R.; Marais, R.; Quezada, S.A.; et al. Cyclooxygenase-Dependent Tumor Growth through Evasion of Immunity. Cell 2015, 162, 1257-1270. [CrossRef] [PubMed]

89. Rooney, M.S.; Shukla, S.A.; Wu, C.J.; Getz, G.; Hacohen, N. Molecular and genetic properties of tumors associated with local immune cytolytic activity. Cell 2015, 160, 48-61. [CrossRef]

90. DeLeon, T.T.; Almquist, D.R.; Kipp, B.R.; Langlais, B.T.; Mangold, A.; Winters, J.L.; Kosiorek, H.E.; Joseph, R.W.; Dronca, R.S.; Block, M.S.; et al. Assessment of clinical outcomes with immune checkpoint inhibitor therapy in melanoma patients with CDKN2A and TP53 pathogenic mutations. PLoS ONE 2020, 15, e0230306. [CrossRef]

91. Helgadottir, H.; Ghiorzo, P.; van Doorn, R.; Puig, S.; Levin, M.; Kefford, R.; Lauss, M.; Queirolo, P.; Pastorino, L.; Kapiteijn, E.; et al. Efficacy of novel immunotherapy regimens in patients with metastatic melanoma with germline CDKN2A mutations. $J$. Med. Genet. 2020, 57, 316-321. [CrossRef]

92. Lv, F.; Wu, J.; Miao, D.; An, W.; Wang, Y. p16 deficiency promotes nonalcoholic steatohepatitis via regulation of hepatic oxidative stress. Biochem. Biophys. Res. Commun. 2017, 486, 264-269. [CrossRef] [PubMed]

93. Chin, L.; Pomerantz, J.; Polsky, D.; Jacobson, M.; Cohen, C.; Cordon-Cardo, C.; Horner, J.W., 2nd; DePinho, R.A. Cooperative effects of INK4a and ras in melanoma susceptibility in vivo. Genes Dev. 1997, 11, 2822-2834. [CrossRef] [PubMed]

94. Krimpenfort, P.; Quon, K.C.; Mooi, W.J.; Loonstra, A.; Berns, A. Loss of p16Ink4a confers susceptibility to metastatic melanoma in mice. Nature 2001, 413, 83-86. [CrossRef] [PubMed]

95. Che, H.; Li, J.; Li, Y.; Ma, C.; Liu, H.; Qin, J.; Dong, J.; Zhang, Z.; Xian, C.J.; Miao, D.; et al. p16 deficiency attenuates intervertebral disc degeneration by adjusting oxidative stress and nucleus pulposus cell cycle. eLife 2020, 9, e52570. [CrossRef] [PubMed]

96. Kyritsi, K.; Francis, H.; Zhou, T.; Ceci, L.; Wu, N.; Yang, Z.; Meng, F.; Chen, L.; Baiocchi, L.; Kundu, D.; et al. Downregulation of p16 Decreases Biliary Damage and Liver Fibrosis in the Mdr2(/) Mouse Model of Primary Sclerosing Cholangitis. Gene Expr. 2020, 20, 89-103. [CrossRef] [PubMed]

97. Faget, D.V.; Ren, Q.; Stewart, S.A. Unmasking senescence: Context-dependent effects of SASP in cancer. Nat. Rev. Cancer 2019, 19, 439-453. [CrossRef]

98. Zhang, H.; Chen, Z.H.; Savarese, T.M. Codeletion of the genes for p16INK4, methylthioadenosine phosphorylase, interferonalpha1, interferon-beta1, and other 9p21 markers in human malignant cell lines. Cancer Genet. Cytogenet. 1996, 86, 22-28. [CrossRef] 
99. Roy, D.M.; Walsh, L.A.; Desrichard, A.; Huse, J.T.; Wu, W.; Gao, J.; Bose, P.; Lee, W.; Chan, T.A. Integrated Genomics for Pinpointing Survival Loci within Arm-Level Somatic Copy Number Alterations. Cancer Cell 2016, 29, 737-750. [CrossRef]

100. Kim, H.; Kim, H.; Feng, Y.; Li, Y.; Tamiya, H.; Tocci, S.; Ronai, Z.A. PRMT5 control of cGAS/STING and NLRC5 pathways defines melanoma response to antitumor immunity. Sci. Transl. Med. 2020, 12, eaaz5683. [CrossRef] [PubMed]

101. Dou, Z.; Ghosh, K.; Vizioli, M.G.; Zhu, J.; Sen, P.; Wangensteen, K.J.; Simithy, J.; Lan, Y.; Lin, Y.; Zhou, Z.; et al. Cytoplasmic chromatin triggers inflammation in senescence and cancer. Nature 2017, 550, 402-406. [CrossRef]

102. Ivanov, A.; Pawlikowski, J.; Manoharan, I.; van Tuyn, J.; Nelson, D.M.; Rai, T.S.; Shah, P.P.; Hewitt, G.; Korolchuk, V.I.; Passos, J.F.; et al. Lysosome-mediated processing of chromatin in senescence. J. Cell Biol. 2013, 202, 129-143. [CrossRef] [PubMed]

103. Gluck, S.; Guey, B.; Gulen, M.F.; Wolter, K.; Kang, T.W.; Schmacke, N.A.; Bridgeman, A.; Rehwinkel, J.; Zender, L.; Ablasser, A. Innate immune sensing of cytosolic chromatin fragments through cGAS promotes senescence. Nat. Cell Biol. 2017, 19, 1061-1070. [CrossRef] [PubMed]

104. Linsley, P.S.; Speake, C.; Whalen, E.; Chaussabel, D. Copy number loss of the interferon gene cluster in melanomas is linked to reduced T cell infiltrate and poor patient prognosis. PLoS ONE 2014, 9, e109760. [CrossRef] [PubMed]

105. Xue, W.; Zender, L.; Miething, C.; Dickins, R.A.; Hernando, E.; Krizhanovsky, V.; Cordon-Cardo, C.; Lowe, S.W. Senescence and tumour clearance is triggered by p53 restoration in murine liver carcinomas. Nature 2007, 445, 656-660. [CrossRef]

106. Braumuller, H.; Wieder, T.; Brenner, E.; Assmann, S.; Hahn, M.; Alkhaled, M.; Schilbach, K.; Essmann, F.; Kneilling, M.; Griessinger, C.; et al. T-helper-1-cell cytokines drive cancer into senescence. Nature 2013, 494, 361-365. [CrossRef]

107. Brenner, E.; Schorg, B.F.; Ahmetlic, F.; Wieder, T.; Hilke, F.J.; Simon, N.; Schroeder, C.; Demidov, G.; Riedel, T.; Fehrenbacher, B.; et al. Cancer immune control needs senescence induction by interferon-dependent cell cycle regulator pathways in tumours. Nat. Commun. 2020, 11, 1335. [CrossRef]

108. Hilke, F.J.; Sinnberg, T.; Gschwind, A.; Niessner, H.; Demidov, G.; Amaral, T.; Ossowski, S.; Bonzheim, I.; Rocken, M.; Riess, O.; et al. Distinct Mutation Patterns Reveal Melanoma Subtypes and Influence Immunotherapy Response in Advanced Melanoma Patients. Cancers 2020, 12, 2359. [CrossRef]

109. Stein, G.H.; Drullinger, L.F.; Soulard, A.; Dulic, V. Differential roles for cyclin-dependent kinase inhibitors p21 and p16 in the mechanisms of senescence and differentiation in human fibroblasts. Mol. Cell. Biol. 1999, 19, 2109-2117. [CrossRef]

110. Novais, E.J.; Diekman, B.O.; Shapiro, I.M.; Risbud, M.V. p16(Ink4a) deletion in cells of the intervertebral disc affects their matrix homeostasis and senescence associated secretory phenotype without altering onset of senescence. Matrix Biol. 2019, 82, 54-70. [CrossRef] 